\title{
Review - Nutraceuticals Can Target Asthmatic Bronchoconstriction: NADPH Oxidase- Dependent Oxidative Stress, RhoA and Calcium Dynamics
}

\author{
Mark F McCarty' \\ James J DiNicolantonio ${ }^{2}$ \\ Aaron Lerner $\mathbb{D}^{3}$ \\ 'Catalytic Longevity Foundation, San \\ Diego, CA, USA; 'Department of \\ Preventive Cardiology, Saint Luke's Mid \\ America Heart Institute, Kansas, MO, \\ USA; ${ }^{3}$ Chaim Sheba Medical Center, The \\ Zabludowicz Research Center for \\ Autoimmune Diseases, Tel Hashomer, \\ 5262000, Israel
}

\begin{abstract}
Activation of various isoforms of NADPH oxidase contributes to the pathogenesis of asthma at multiple levels: promoting hypercontractility, hypertrophy, and proliferation of airway smooth muscle; enabling lung influx of eosinophils via VCAM-1; and mediating allergen-induced mast cell activation. Free bilirubin, which functions physiologically within cells as a feedback inhibitor of NADPH oxidase complexes, has been shown to have a favorable impact on each of these phases of asthma pathogenesis. The spirulina chromophore phycocyanobilin (PhyCB), a homolog of bilirubin's precursor biliverdin, can mimic the inhibitory impact of biliverdin/bilirubin on NADPH oxidase activity, and spirulina's versatile and profound anti-inflammatory activity in rodent studies suggests that PhyCB may have potential as a clinical inhibitor of NADPH oxidase. Hence, spirulina or PhyCBenriched spirulina extracts merit clinical evaluation in asthma. Promoting biosynthesis of glutathione and increasing the expression and activity of various antioxidant enzymes - as by supplementing with $\mathrm{N}$-acetylcysteine, Phase 2 inducers (eg, lipoic acid), selenium, and zinc may also blunt the contribution of oxidative stress to asthma pathogenesis. Nitric oxide (NO) and hydrogen sulfide $\left(\mathrm{H}_{2} \mathrm{~S}\right)$ work in various ways to oppose pathogenic mechanisms in asthma; supplemental citrulline and high-dose folate may aid NO synthesis, high-dose biotin may mimic and possibly potentiate NO's activating impact on soluble guanylate cyclase, and NAC and taurine may boost $\mathrm{H}_{2} \mathrm{~S}$ synthesis. The amino acid glycine has a hyperpolarizing effect on airway smooth muscle that is bronchodilatory. Insuring optimal intracellular levels of magnesium may modestly blunt the stimulatory impact of intracellular free calcium on bronchoconstriction. Nutraceutical regimens or functional foods incorporating at least several of these agents may have utility as nutraceutical adjuvants to standard clinical management of asthma.
\end{abstract}

Keywords: asthma, bronchoconstriction, calcium, NADPH oxidase, RhoA, oxidative stress

\section{Introduction}

Asthma is a chronic inflammation of the airways of the lungs, characterized by reversible airflow obstruction, variable and recurring symptoms, and allergen triggered bronchospasms. ${ }^{1}$ Genetic and environmental factors are predisposing factors and wheezing, shortness of breath, coughing and chest tightness are frequent presenting symptoms. Asthma is thought to afflict about 300 million people worldwide, and its prevalence over the last several decades has increased markedly. ${ }^{2}$ There is no
Correspondence: Aaron Lerner Chaim Sheba Medical Center, The Zabludowicz Research Center for Autoimmune Diseases,

Tel Hashomer, 5262000, Israel

Tel +972-525-919484

Email aaronlerner1948@gmail.com 
definitive cure for the disease. Symptoms can be prevented by avoiding allergens and irritants, or treated by inhaled corticosteroids, long-acting beta agonists or antileukotriene agents. ${ }^{3}$ Various diets and food supplements have been suggested for aiding asthma control, but a comprehensive review describing how nutraceuticals might target asthmatic bronchoconstriction is lacking. ${ }^{4}$ This review summarizes what is known regarding the molecular biology underlying the pathogenesis of asthma, focusing in particular on the role played by reactive oxygen species generated by NADPH oxidase complexes, and proposes that certain specific nutraceuticals have potential for asthma control, meriting clinical evaluation in this regard.

\section{Pathogenesis of Allergic Asthma}

Allergic asthma constitutes an inflammatory stew in which Th2 lymphocytes, mast cells, basophils, and eosinophils, in response to an allergen challenge, congregate in the lung and produce a range of autacoids and toxins that increase resistance to air flow both by inducing bronchoconstriction and by increasing mucus production. ${ }^{5}$ In the longer term, bronchial hyperplasia can evolve, further increasing airway resistance in a manner not susceptible to acute therapeutic control. ${ }^{6}$

\section{Mechanisms of Bronchoconstriction in Asthma}

Figure 1 provides an overview of the molecular biology underlying asthmatic bronchoconstriction. Autacoids such as histamine, prostaglandins and leukotrienes act via $\mathrm{G}$ protein-coupled receptors to induce activation of the

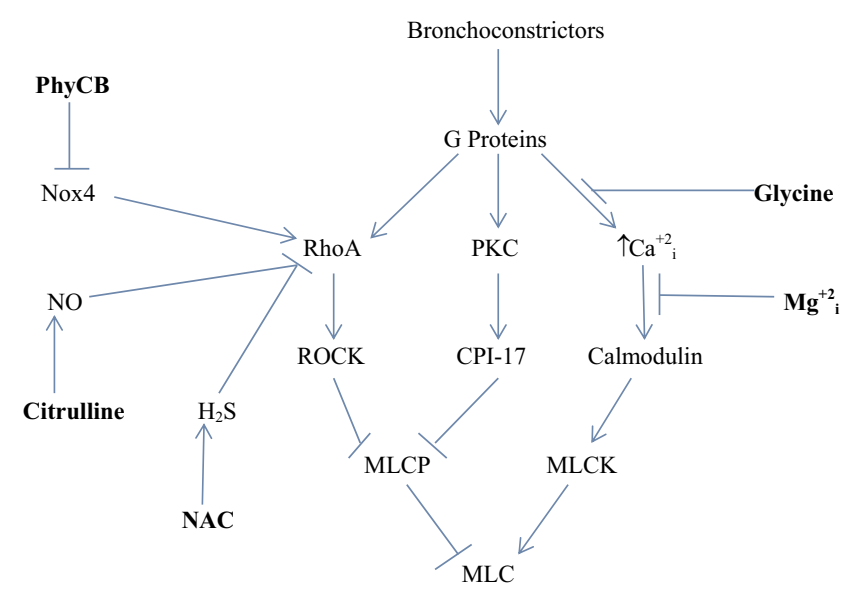

Bronchoconstriction

Figure I Regulation of bronchial constriction. Nutraceuticals with potential for intervening in this process are highlighted in bold. i-intracellular.
G protein RhoA and phospholipase C, while exerting a depolarizing effect on smooth muscle plasma membrane that promotes calcium influx via voltage-gated calcium channels. $^{7}$ RhoA activity is boosted by $\mathrm{G}_{12 / 13}$-mediated activation of RhoA GEFs (guanosine nucleotide exchange factors) that induce RhoA binding to GTP. ${ }^{7,8}$ Activated RhoA then stimulates Rho-activated kinase (ROCK), which confers an inhibitory phosphorylation on the myosin light chain phosphatase (MLCP) complex. $^{7}$ Concurrently, this complex is also inhibited by the protein CPI-17; the inhibitory efficacy of this protein is activated by a phosphorylation conferred by protein kinase $\mathrm{C}$ (PKC), which in turn is activated by $\mathrm{G}$ proteinmediated stimulation of phospholipase $\mathrm{C}$ activity (PLC). ${ }^{9}$ Meanwhile, broncho-constrictive autacoids boost the activity of myosin light chain kinase by inducing calcium influx via L-type voltage-sensitive calcium channels; these autacoids promote a depolarization of the plasma membrane that induces this influx. With respect to histamine, stimulation of $\mathrm{H} 1$ receptors activates $\mathrm{PKC}$, which in turn confers an inhibitory phosphorylation on Kv7.5 potassium channels, resulting in depolarization and consequent calcium influx. $^{10,11}$ The net impact of these mechanisms is to boost the activity of MLCK while suppressing that of MLCP, amplifying the Ser-19 phosphorylation of the 20 $\mathrm{kDa}$ myosin light chain that induces smooth muscle constriction. $^{12,13}$

The bronchial smooth muscle of asthmatics typically displays increased expressions of the Nox4 isoform of NADPH oxidase; moreover, the hypersensitivity of asthmatic bronchial smooth muscle to bronchoconstrictors is ameliorated by inhibition of Nox $4 .{ }^{14}$ This may reflect an oxidant-induced amplification of RhoA expression and activity. Oxidant production by Nox 4 has been shown to increase RhoA/ROCK expression in vascular smooth muscle, and other studies show that stimulation of oxidant production in smooth muscle boosts RhoA activity or expression. ${ }^{15-18}$ One possible explanation for this phenomenon is that oxidants suppress the expression of MiR-133a, which targets the 3' untranslated region of RhoA mRNA, promoting its degradation; hence, oxidants would be expected to up-regulate RhoA mRNA. ${ }^{18}$ The Th2-generated cytokines IL-4 and IL-13 can also increase RhoA expression in bronchial smooth muscle. ${ }^{19}$ On the other hand, activation of RhoA is opposed by the bioactivities of both nitric oxide (NO) and hydrogen sulfide $\left(\mathrm{H}_{2} \mathrm{~S}\right)$. NO-mediated activation of soluble guanylate cyclase (sGC) stimulates synthesis of cyclic GMP (cGMP), 
which in turn binds to and activates protein kinase $\mathrm{G}$ (PKG). Activated PKG can then confer a phosphorylation on RhoA that prevents it from interacting with its GEF and binding GTP. ${ }^{20,21} \mathrm{H}_{2} \mathrm{~S}$ can interact directly with RhoA via reversible S-sulfhydration of a cysteine group; this likewise prevents the activation of RhoA. ${ }^{22,23}$ Concurrently, $\mathrm{H}_{2} \mathrm{~S}$ acts to upregulate $\mathrm{NO}$ bioactivity, by reversing a peroxynitrite-mediated oxidation of sGC that renders it non-responsive to $\mathrm{NO}^{24} \mathrm{H}_{2}$ $\mathrm{S}$ can also boost cellular cGMP levels via inhibition of phosphodiesterase-5, which degrades cGMP. ${ }^{25,26}$ Hence, measures which inhibit Nox4 activity, amplify or mimic NO bioactivity, or boost $\mathrm{H}_{2} \mathrm{~S}$ synthesis can be expected to oppose bronchoconstriction by decreasing the expression or activation of RhoA.

\section{Multiple Roles for NADPH Oxidase in the Pathogenesis of Asthma}

The foregoing discussion cites evidence that Nox4 overexpression in bronchial smooth muscle is a key mediator of bronchoconstriction in asthma. However, NADPH oxidase activity plays a number of additional key roles in the pathogenesis of asthma:

\section{Airway Smooth Muscle Hypertrophy and Hyperplasia}

The hypertrophic and proliferative response of airway smooth muscle (ASM) cells in culture to serum or agonists such as TGF- $\beta 1$ appears to likewise be mediated by Nox 4 activation, as silencing of Nox 4 or other measures known to inhibit NADPH oxidase activity render ASM more quiescent. ${ }^{27-29}$ Pertinent downstream targets activated by Nox4-induced oxidants include NF-kappaB, ERK1/2, and mTORC1. Expansion of airway smooth muscle mass is a common feature of chronic asthma, leading to persistent smooth airway obstruction not reversible with bronchodilators.

\section{Ciliary Dysfunction}

In airway epithelium, reduced cilia beat frequency is observed in patients with a neutrophilic subtype of asthma; this impairs mucus clearance and is linked to increased risk for lung infections. ${ }^{30,31}$ Studies with ex vivo epithelial strips from such patients indicate that Nox4 is overexpressed in this epithelium, and that reduction in beat frequency is reversed by a chemical that inhibits specifically the Nox 1 and Nox4 isoforms of NADPH oxidase. ${ }^{31}$

\section{Eosinophil Influx}

Pulmonary eosinophilia is a typical feature of asthma, and is suspected to exacerbate the syndrome by release of various pro-inflammatory mediators. ${ }^{32}$ Circulating eosinophils access the lung parenchyma via VCAM-1 receptors on lung endothelial cells. ${ }^{33,34}$ (Lymphocytes also employ this transit mechanism, although they are less obligately dependent upon it.) Engagement of endothelial VCAM-1 receptors by eosinophils induces activation of Nox2dependent NADPH oxidase activity in endothelium, and the resulting oxidant production plays an obligate role in enabling infiltration of eosinophils into the lung. ${ }^{35,36}$ Hence, in Nox2-knockout mice rendered chimeric by irradiation and implantation of wild-type hematopoietic cells, lung eosinophil influx following intranasal challenge with ovalbumin (in mice previously sensitized to this protein) is substantially blunted in contrast to wild-type mice; moreover, the airway hyperresponsiveness following ovalbumin challenge is likewise blunted in these chimeric mice, consistent with a role for eosinophil influx in airway obstruction. $^{37}$

\section{Mast Cell Activation}

Agonists which promote mast cell degranulation, and boost mast cell production of Th2 cytokines such as IL-4 and IL-13, do so via a signaling pathway obligately dependent on NADPH oxidase activation. ${ }^{38-40}$ Mast cell activation evidently plays a crucial role in allergic asthma.

Evidently, agents which can safely down-regulate NADPH oxidase activity, or which counteract the signaling impact of oxidants by either promoting catabolism of oxidants, or by acting to reverse the oxidation of acidic cysteine groups induced by hydrogen peroxide, should have interesting potential for preventing or controlling asthma. Figure 2 depicts the multiple roles of NADPH oxidase-generated oxidants in the pathogenesis of asthma.

\section{Nutraceutical Strategies for Controlling NADPH Oxidase Activity}

These considerations suggest that therapeutic strategies capable of safely down-regulating NADPH oxidase activation in the lung could have major potential for controlling asthma. Indeed, systemic administration of the NADPH oxidase-inhibitory agent apocynin notably blunts airway hyperresponsiveness and lung inflammation in sensitized mice challenged with ovalbumin. ${ }^{41}$ In mild human 


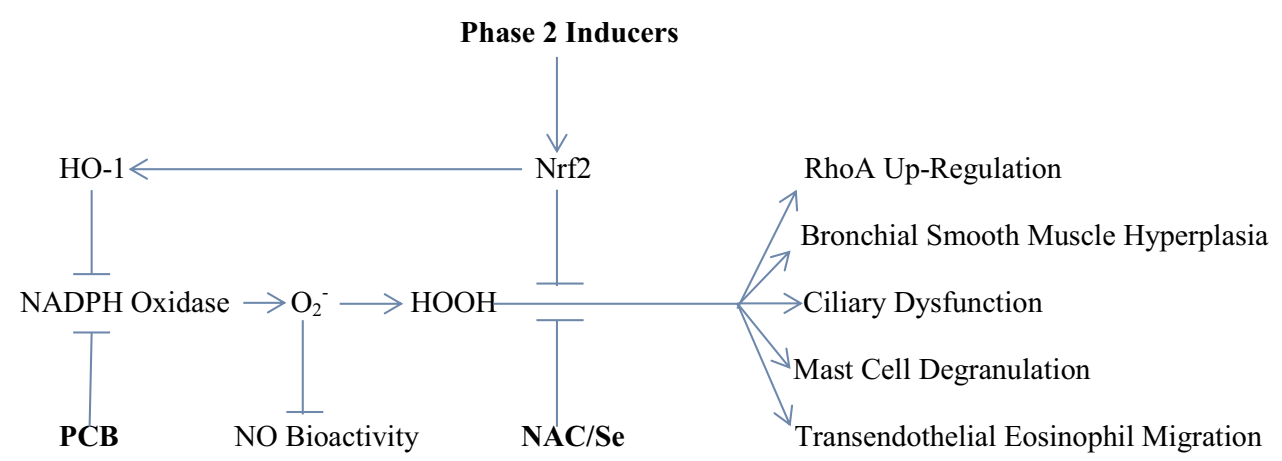

Figure 2 The multiple roles of NADPH oxidase-driven oxidative stress in the pathogenesis of asthma. Nutraceuticals with potential for intervening in this process are highlighted in bold.

asthmatics, inhalation of aerosolized apocynin prior to and during exposure to ozone blunted the subsequent airway hyperresponsiveness in response to methacholine. ${ }^{42}$

Moreover, recent research has established that the profound physiological antioxidant activity of bilirubin observed intracellularly at low nanomolar concentrations reflects inhibition of NADPH oxidase complexes; the mechanism and isoform specificity of this effect requires further clarification. ${ }^{43-46}$ When cells are oxidatively stressed - oftentimes by overactivation of NADPH oxidase - induction of heme oxygenase-1 results in breakdown of heme, yielding carbon monoxide and biliverdin; the latter is quickly reduced to bilirubin, which provides feedback inhibition of NADPH oxidase. ${ }^{46}$ Ohrui and colleagues have reported an intriguing case history in which a teenager with chronic hard-to-control asthma was hospitalized for acute hepatitis B. ${ }^{47}$ The patient's serum bilirubin level tripled during the course of his hospital stay, and his physicians were intrigued to note that his intractable asthma almost completely remitted during this time, such that asthma medications could be discontinued. However, within a couple of weeks, his bilirubin levels normalized - and this was associated with return of his asthma. His physicians insightfully suggested that the antioxidant activity of bilirubin may have been responsible for his temporary remission.

Experimental studies likewise suggest that bilirubin may function physiologically to quell the asthma syndrome. In a mouse model of allergic asthma engendered by repeated nasal administration of aspergillus/ovalbumin proteins, i.p or i.v. administration of bilirubin nanoparticles markedly reduced airway hyperresponsiveness to methacholine, decreased cell count in bronchoalveolar fluid (BALF), and suppressed eosinophil influx. ${ }^{48}$ In vitro, bilirubin has been shown to impede VCAM- 1-dependent trans endothelial migration; in a murine asthma model, i.p. administration of bilirubin was found to suppress lung infiltration by eosinophils and lymphocytes. ${ }^{49}$ The ability of heme oxygenase-1 induction to antagonize ASM cell hypercontractility and proliferation has been traced to the bilirubin generated by this enzyme. ${ }^{50,51}$ Analogously, exposure of mast cells to low micromolar concentrations of bilirubin opposes agonistinduced degranulation and up-regulation of adhesion, mimicking the impact of heme oxygenase-1 induction in this regard. ${ }^{52,53}$ Hence, bilirubin has been shown to antagonize most of the NADPH oxidase-dependent phases of asthma pathogenesis highlighted above.

\section{Phycocyanobilin as a Clinically Feasible NADPH Oxidase Inhibitor}

Unfortunately, bilirubin is unsuitable for oral administration owing to its marked insolubility; its more soluble precursor biliverdin is more feasible in this respect, but there are no known rich sources of this chemical, and it is expensive to synthesize. It is therefore quite propitious that cyanobacteria such as spirulina are very rich sources about $0.6 \%$ by dry weight - of the chromophore phycocyanobilin (PhyCB), a biliverdin metabolite. ${ }^{54}$ Within cells, PhyCB is quickly converted to phycocyanorubin, whose structure is quite similar to that of bilirubin. ${ }^{55}$ Indeed, PhyCB, likely via its metabolite phycocyanorubin, has been shown to inhibit NADPH oxidase complexes in vitro and in vivo with a dose-dependent potency similar to that observed with biliverdin/bilirubin. ${ }^{54,56}$ This phenomenon likely explains why oral administration of spirulina or of phycocyanin (the spirulina protein which contains PhyCB as a covalently attached chromophore) has exerted profound anti-inflammatory effects in a host of rodent models of inflammation. ${ }^{54,57}$ Oral phycocyanin 
has shown marked anti-atherosclerotic activity in cholesterol-fed hamsters, and nearly completely prevented nephrosclerosis in diabetic mice - syndromes known to be driven, in part, by NADPH oxidase activation. ${ }^{56,58}$

In light of the foregoing discussion, it seems quite reasonable to propose that an adequate intake of spirulina, phycocyanin, or PhyCB-enriched spirulina extracts may have important clinical utility in asthma. Of course, this hinges on the presumption that humans can absorb and metabolize PhyCB much like rodents do - a proposal which still requires clinical confirmation. Arguably, assessing the clinical impact of high-dose spirulina on asthma could be a quick and highly feasible way of confirming that PhyCB has the antioxidant/anti-inflammatory potential in humans that it clearly does in rodents. Extrapolating from the doses that have proved highly effective in rodent models, it has been estimated that humans might need to take 15-30 g spirulina daily - or the equivalent intake of PhyCB - to achieve optimal anti-inflammatory effects. ${ }^{54}$ However, a small non-blinded controlled trial in adult asthmatics found that one gram daily of spirulina provided clinical benefit comparable to standard medication, and that the combination of spirulina with medication produced the best clinical outcomes. ${ }^{59}$ A comparable study in a larger group with a higher dose of spirulina would be warranted.

Moreover, if PhyCB can function as a clinically feasible NADPH oxidase inhibitor in humans, there is reason to suspect that it may have much broader utility for lung protection. A recent massive prospective epidemiological analysis in the UK found that people with relatively high serum bilirubin levels were at notably lower risk for both lung cancer and chronic obstructive pulmonary diseases an effect which arguably could reflect down-regulated activity of NADPH oxidase complexes in lung tissue. ${ }^{60}$ Intravenous bilirubin infusion protects rats from bleomycin-induced pulmonary fibrosis, likely reflected the role of NADPH oxidase in TGF-beta signaling. ${ }^{61}$ The same clinical group which noted improvement of asthma in a patient during an episode of temporary hyperbilirubinemia, also reported resolution of idiopathic pulmonary fibrosis in a patient who developed sustained elevated bilirubin owing to biliary tract obstruction. ${ }^{62}$ The hypercontractility and hyperplasia of pulmonary vascular smooth muscle triggered by chronic hypoxia during the onset of pulmonary hypertension, appears to be mediated by oxidative stress in this vascular muscle that stems from both mitochondria and NADPH oxidase. ${ }^{17,63-65}$ The overexuberant lung inflammation that mediates death in "killer" influenzas appears to reflect viral activation of NADPH oxidase in lung epithelium. ${ }^{66-68}$ Endotoxin-induced acute lung injury in rats - a model for acute respiratory distress syndrome - is substantially blunted by biliverdin administration; mortality is also markedly decreased. ${ }^{69}$ NADPH oxidase activation seems likely to play a pathogenic role in cystic fibrosis. $^{70,71}$ It can be concluded that, if spirulina/ PhyCB do indeed have useful clinical activity in asthma, they may have a much broader potential for promotion of pulmonary health.

There is also some evidence that spirulina, and perhaps PhyCB, has the potential to down-regulate the induction of Th2 cells that play a central role in the pathogenesis of asthma and allergic rhinitis. In a double-blind trial, administration of $2 \mathrm{~g}$ spirulina daily was found to lower the ex vivo production of phytohaemaglutinin-stimulated peripheral blood mononuclear cells by a significant $32 \%{ }^{72}$ Such an effect could be expected to diminish the differentiation of Th2 cells. This is paralleled by evidence that i.p. administration of bilirubin can reduce BLF content of the Th2 cytokines IL-4, IL-5, and IL-13; moreover, in vitro, bilirubin nanoparticles dose-dependently reduce the induction of IL-4-producing $\mathrm{T}$ cells in stimulated $\mathrm{CD} 4+$ lymphocytes. ${ }^{48}$ Curiously, there is also evidence that bilirubin/biliverdin and PhyCB may modulate T cell development by promoting induction of Treg cells. ${ }^{73-75}$ This latter effect might hinge on the ability of bilirubin (and possibly PhyCB's metabolite phycocyanorubin?) to act as an agonist for the arylhydrocarbon receptor, which likewise promotes Treg induction. ${ }^{76-78}$

\section{Increasing Lung Glutathione Levels May Counter Some Pathogenic Effects of Oxidative Stress}

Many of the pro-inflammatory effects of oxidative stress including presumably some of those stemming from Nox4 activity in asthma - are mediated by hydrogen peroxide, which oxidizes acidic cysteine groups in signaling proteins or enzymes to sulfenic acid. ${ }^{79,80}$ Reduced glutathione, working in concert with glutaredoxin, can reverse these oxidations, restoring protein-bound cysteine to its native form. $^{81-83}$ In this way, glutathione works to counteract oxidant-induced pro-inflammatory signaling. The availability of cysteine is rate-limiting for glutathione synthesis, and many studies - both in rodents and humans - demonstrate that supplementation with $\mathrm{N}$-acetylcysteine (NAC) 
can increase tissue glutathione levels; ${ }^{84,85} \mathrm{NAC}$ is better tolerated and more stable than free cysteine when administered orally, and readily gives rise to free cysteine once absorbed. Hence, there is reason to suspect that supplemental NAC could aid control of asthma. Indeed, two groups have reported favorable effects of NAC administration in ovalbumin-induced asthma in rodents. ${ }^{86-88}$ In a controlled clinical study, enrolling individuals hyperresponsive to methacholine challenge, 6 days of NAC pretreatment (600 $\mathrm{mg}$ three time daily) reduced baseline methacholine responsiveness by about $20 \%$, and also blunted the ability of diesel exhaust to increase airway hyperresponsiveness. ${ }^{89}$ However, a controlled trial of NAC (600 mg twice daily) in patients experiencing asthma exacerbations failed to observe clinical benefit. ${ }^{90}$

Glutathione synthesis can also be promoted by administration of so-called phase 2 inducers, which stimulate activity of the nrf 2 transcription factor to increase expression of a number of antioxidant enzymes, including $\gamma-$ glutamylcysteine synthetase, rate-limiting for glutathione synthesis. ${ }^{91}$ Enzymes whose expression is enhanced by phase 2 inducers work in conjunction with glutathione and the small proteins thioredoxin and glutaredoxin to catabolize oxidants such as hydrogen peroxide, or to reverse the oxidizing impact of hydrogen peroxide on protein sulfhydryl groups. The most clinically developed of phase 2 inducers is the natural cofactor lipoic acid (LA), which has been shown to be therapeutically beneficial in diabetic neuropathy in doses of $600 \mathrm{mg}$ 2-3 times daily. ${ }^{92,93}$ LA administration has been evaluated in ovalbumin-induced asthma in mice; LA decreased airway hyperresponsiveness, eosinophil influx, and markers of oxidative stress in bronchoalveolar lavage fluid. ${ }^{94}$ In a longer term study in this model, LA administration suppressed airway remodeling. ${ }^{95}$ The natural phase 2 inducer ferulic acid, used in China as a medication for cardiovascular disorders, likewise has been found to ameliorate ovalbumin-induced asthma in mice. ${ }^{96,97}$

Phase 2 inducers have the additional merit of boosting expression of heme oxygenase-1, which degrades heme to generate free bilirubin within cells. ${ }^{98}$ This effect could evidently complement the utility of PhyCB for suppressing NADPH oxidase activity within the lung.

The essential mineral selenium is an obligate component of certain phase 2-inducible antioxidant enzymes, including thioredoxin reductase and various isoforms of glutathione reductase. ${ }^{99}$ Hence, it is reasonable to presume that achieving adequate selenium status in asthma patients with poor baseline selenium nutrition may favorably impact asthma control. Indeed, a recent meta-analysis has concluded that patients with asthma tend to have lower plasma selenium levels than controls. ${ }^{100}$

\section{$\mathrm{NO}$ and $\mathrm{H}_{2} \mathrm{~S}$ Bioactivity Both Oppose Pathogenic Mechanisms in Asthma}

In the healthy lung, nitric oxide (NO), produced primarily by airway epithelium, vascular endothelium, and neurons via the constitutive endothelial and neuronal forms of NO synthase, acts directly on bronchial smooth muscle to promote bronchodilation and oppose hypertrophy and hyperplasia. ${ }^{101-104}$ NO produced by airway epithelium boosts ciliary beat frequency. ${ }^{105,106}$ NO production by vascular endothelium opposes the influx of eosinophils into lung parenchyma. ${ }^{107-110}$ The effects of NO bioactivity on bronchial smooth muscle, epithelial ciliary function, trans endothelial eosinophil influx, and mast cell activity are in opposition to those of lung oxidative stress, which is not entirely coincidental, as superoxide and its downstream products act in various ways to oppose NO bioactivity. Superoxide reacts avidly and spontaneously with NO to produce the potent oxidant peroxynitrite; peroxynitrite, in turn, can cause an inhibitory oxidation of sGC, and also cause uncoupling of NO synthase via oxidation of its obligate cofactor tetrahydrobiopterin. ${ }^{111,112}$ Oxidative stress can also impair the activity of dimethylarginine dimethylaminohydrolase (DDAH), the enzyme which catabolizes the natural metabolite asymmetric dimethylarginine (ADMA). ${ }^{113}$ The latter also uncouples NO synthase, so a deficit in DDAH activity tends to promote this uncoupling by boosting tissue levels of ADMA. ${ }^{114}$ Conversely, genetic overexpression of DDAH1 in mouse models of asthma attenuates lung inflammation, presumably by enhancing coupled NO synthase activity. ${ }^{115}$

Theoretically, nutraceutical measures which boost NO synthase activity should be helpful in asthma control. However, in seeming paradox, exhalation of NO in asthma patients tends to be elevated, reflecting the ability of proinflammatory cytokines in the lungs to boost expression of the inducible form of NO synthase (iNOS). ${ }^{116-118}$ Indeed, higher levels of exhalate NO tend to correlate with severe disease in asthma patients, associated with greater inflammation within the lungs. ${ }^{114,119}$ The failure of this elevated NO production to confer notable benefit in asthma patients appears to reflect impaired activity of sGC. This 
impairment is attributable, in part, to oxidative inactivation of sGC, likely mediated by peroxynitrite. ${ }^{111}$ Additionally, the expression of $\mathrm{sGC}$, both at the mRNA and protein level, is reduced in the ASM of mice with ovalbumininduced asthma; why this occurs remains mysterious. $^{120,121}$

Measures which promote proper coupling of $\mathrm{NO}$ synthase should be doubly beneficial for asthma control, as these could be expected both to enhance NO production and bioactivity, and to decrease production of superoxide. ${ }^{114}$ Blood and lung levels of ADMA tend to be elevated in asthma patients; indeed, elevation of ADMA may be a key reason why obesity tends to increase asthma severity. ${ }^{115,122-126}$ Moreover, increases in lung arginase expression in asthma diminish the arginine/ ADMA ratio, further promoting uncoupling of $\mathrm{NO}$ synthase. Nutritional elevation of plasma and tissue arginine levels - most effectively achieved by supplementation with the arginine precursor citrulline ${ }^{127,128}$ - promotes recoupling of NO synthase in the context of elevated ADMA and arginase. ${ }^{14,129}$ (Indeed, citrulline functions as a competitive inhibitor of arginase. ${ }^{130}$ ) Hence, citrulline supplementation may exert an antioxidant effect on the lungs of asthmatics, while concurrently boosting NO production. Arginine supplementation has provided benefit in several rodent models of asthma - albeit not all. ${ }^{131-135}$ Conversely, elevation of plasma ADMA via continuous subcutaneous infusion potentiates ovalbumin-induced allergic lung inflammation in mice, whereas DDAH1 overexpression is protective in this regard. ${ }^{136}$ In a recent open clinical study, obese asthmatics with NO exhalation in the low-normal range were treated with $15 \mathrm{~g}$ citrulline daily for a minimum of 14 days; forced vital capacity and an index of quality of control improved slightly but significantly, exhalation of NO increased, and the plasma ratio of arginine to ADMA nearly doubled. ${ }^{137}$

With respect to the possibility that increased ADMA is a mediator of the greater severity of asthma in diabetics, it is of interest that treatment with the drug metformin, which has been shown to lower ADMA levels in diabetics, has been associated epidemiologically with lower risk for asthma in diabetics, and better control of asthma in diabetics who already have it. ${ }^{138-140}$ Hence, metformin may be a good therapy choice in asthmatic diabetics. Berberine, an herbally-derived nutraceutical used commonly for diabetes treatment in China, and which replicates metformin's ability to activate AMP-activated kinase, has been shown to favorably influence ovalbumin-induced asthma in rats. $^{141}$

It seems likely that peroxynitrite-mediated oxidation of tetrahydrobiopterin also contributes to uncoupling of lung NO synthase in asthma. ${ }^{112}$ When the vascular system is under oxidative stress, administration of high-dose folate (eg, 10-80 mg daily) helps to recouple eNOS. ${ }^{142-145}$ This seems to reflect two effects. Reduced metabolites of folate produced within cells are effective scavengers of peroxynitrite-derived radicals (an effect that might conceivably protect sGC activity as well). ${ }^{146}$ Moreover, high levels of folate induce increased expression of dihydrofolate reductase in endothelial cells; this enzyme functions to reduce dihydrobiopterin to tetrahydrobiopterin, reversing the oxidizing impact of peroxynitrite on this cofactor. ${ }^{147-150}$ Whether high-dose folate can exert a comparable inductive effect in lung epithelial cells merits study.

Metallothionein (MT) can function to quench peroxynitrite-derived oxidants, and ovalbumin-induced asthma is more intense in MT-knockout mice. ${ }^{151-153}$ Conversely, zinc supplementation can boost MT expression, which may help to rationalize the favorable impact of zinc supplementation on asthma in pilot clinical trials and in mouse models. ${ }^{154-159}$ A meta-analysis has determined that plasma zinc levels tend to be lower in asthma patients than controls. ${ }^{100}$

Another way to protect sGC from oxidative inhibition is to boost production of hydrogen sulfide $\left(\mathrm{H}_{2} \mathrm{~S}\right)$. This gaseous mediator works in a variety of ways to complement the bioactivity of NO. ${ }^{160}$ In particular, $\mathrm{H}_{2} \mathrm{~S}$, much more effectively than glutathione, can reactivate oxidized sGC by re-reducing it. ${ }^{24}$ Moreover, in cells prominently expressing phosphodiesterase 5 (PDE5), it can up-regulate cGMP levels by inhibiting this enzyme (like the pharmaceutical PDE5 inhibitors used to treat erectile dysfunction). ${ }^{161}$

The primary enzymes which produce $\mathrm{H}_{2} \mathrm{~S}$, using cysteine as a substrate, are cystathionine $\beta$-synthase (CBS) and cystathionine $\gamma$-lyase (CSE); these are expressed in airway smooth muscle, as well as the endothelium and smooth muscle of the pulmonary vasculature. $^{162}$ Serum levels of $\mathrm{H}_{2} \mathrm{~S}$ are depressed in asthma patients - more so in those with disease exacerbations as opposed to stable asthma. ${ }^{163}$ In patients with acute asthma, serum $\mathrm{H}_{2} \mathrm{~S}$ correlates directly with forced expiratory volume in one second $\left(\mathrm{FEV}_{1}\right)$. In mice with ovalbumin-induced asthma, both serum and lung $\mathrm{H}_{2} \mathrm{~S}$ are decreased, as is expression of CBS and CSE in lung 
tissue. $^{164}$ Exogenous $\mathrm{H}_{2} \mathrm{~S}$ (provided via injection of NaHS) improved peak expiratory flow and alleviated lung inflammation in this syndrome - whereas inhibition of CSE with the drug D,L-propylarginine exacerbated it. $^{164}$

$\mathrm{H}_{2} \mathrm{~S}$ can work in a range of ways to ameliorate asthma, and some of these are independent of its amplifying impact on NO bioactivity. ${ }^{162} \mathrm{H}_{2} \mathrm{~S}$ induces relaxation in tracheal smooth muscle by reducing calcium influx - an effect independent of NO. ${ }^{165}$ It also acts in vitro to slow proliferation of ASM and airway fibroblasts, and to stabilize mast cells. ${ }^{166-168} \mathrm{NaSH}_{2}$ administration decreases elevations of eotaxin in the lungs of mice with ovalbumininduced asthma, suggesting that $\mathrm{H}_{2} \mathrm{~S}$ can slow influx of eosinophils. ${ }^{169}$ Hence, its effects on the asthma syndrome appear to be comparable to those of NO.

\section{Supporting Endogenous Production of $\mathrm{H}_{2} \mathrm{~S}$}

Although drugs achieving slow systemic release of $\mathrm{H}_{2}$ $\mathrm{S}$ are being developed, it may be feasible to boost endogenous $\mathrm{H}_{2} \mathrm{~S}$ production with nutraceuticals. Since cysteine availability is not saturating for either CBS or CSE, boosting lung cysteine levels with supplemental NAC can be expected to enhance lung $\mathrm{H}_{2} \mathrm{~S} .{ }^{170}$ Hence, NAC supplementation in asthma may serve a dual purpose, enhancing synthesis of both glutathione and $\mathrm{H}_{2} \mathrm{~S}$.

With respect to the expressions of CBS and CSE, an intriguing recent study has shown that taurine supplementation increases expression of these enzymes in the aorta of mice; moreover taurine dose-dependently increases their expression in human mesenteric arteries ex vivo. ${ }^{171}$ In human hypertensives, oral administration of 1.6 $\mathrm{g}$ taurine daily doubled serum levels of $\mathrm{H}_{2} \mathrm{~S}$, while achieving reductions in both systolic and diastolic blood pressure that were significant with respect to placebo-treated patients. ${ }^{171}$ It is credible to speculate that $\mathrm{H}_{2} \mathrm{~S}$ may be a primary mediator of the anti-atherosclerotic and antihypertensive effects of taurine extensively documented in rodent studies, as $\mathrm{H}_{2} \mathrm{~S}$ is known to work in multiple complementary ways to protect vascular health. ${ }^{170,172,173}$ Whether taurine can influence CBS and CSE expression in lung has not yet been determined. Only a single study has evaluated taurine in a rodent asthma model; 7 days of oral pre-treatment with taurine did not lessen the bronchoconstriction induced by antigen inhalation, but did subsequently decrease hyperresponsiveness to the bronchoconstrictor 5-hydroxytryptamine, while also decreasing eosinophils and markers of oxidative stress in bronchoalveolar lavage fluid. ${ }^{174}$ (Curiously, these effects were quite similar to those which the same group reported with supplemental NAC in the same rodent model though perhaps not surprising if these agents both promote $\mathrm{H}_{2} \mathrm{~S}$ synthesis. ${ }^{86}$ ) More research with taurine in rodent models is evidently warranted.

\section{High-Dose Biotin Can Act as a Direct Activator of Soluble Guanylate Cyclase}

An alternative strategy for boosting NO bioactivity in the lung is to administer drugs that interact directly with sGC to stimulate or activate it. A category of drugs known as sGC stimulators binds to the active (reduced) form of $\mathrm{sGC}$, directly enhancing its activity and boosting its responsiveness to NO exposure. ${ }^{175,176}$ In contrast, sGC activator drugs interact with the oxidized, deactivated form of sGC (and only that form), restoring its ability to produce cGMP. Drugs of both classes have been shown to reverse the hypersensitivity of airway smooth muscle to bronchoconstrictors in allergic asthma in mice. ${ }^{177}$ A sGC stimulator drug, Riociguat, has been approved for treatment of pulmonary hypertension, but has not been studied clinically in asthma. $^{178}$

In concentrations roughly two orders of magnitude higher than the physiological level - readily achievable with affordable supplementation - the vitamin biotin is known to act as an sGC activator, stimulating its production of cGMP 2-3-fold. ${ }^{179-181}$ Whether, like pharmaceutical cGMP activators, biotin also potentiates responsiveness of $\mathrm{sGC}$ to concurrent $\mathrm{NO}$ exposure, has not yet been studied. In spontaneously hypertensive stroke-prone rats, dietary high-dose biotin has been shown to lower blood pressure modestly, while markedly reducing stroke incidence and mortality; concurrent administration of an inhibitor of sGC abrogates the antihypertensive effect of biotin in this model. ${ }^{182}$ Stimulation of sGC might also underlie the favorable impacts of highdose biotin on diabetic control demonstrated in rodents and humans, and there is reason to suspect that the clinical utility of high-dose biotin in multiple sclerosis may reflect this mechanism. ${ }^{183-185}$ Supplemental biotin is well tolerated in daily doses of $100 \mathrm{mg}$ or more, presumably because the maximal stimulation of sGC it can achieve is far lower than maximal response of this enzyme to 
NO. ${ }^{184,186}$ Hence, high-dose biotin may have practical potential for use in asthma management - albeit it has never been tested in rodent models of this disorder, or indeed in any lung disorders.

\section{Glycine and Magnesium Promote Bronchodilation via Calcium Modulation}

Many tissues express strychnine-inhibitable chloride channels which are opened by interaction with the amino acid glycine. The affinity of these channels for glycine is close to normal plasma concentrations, so elevations of plasma glycine achievable through practical supplementation can increase the open probability of these channels. ${ }^{187,188}$ Except in tissues that concentrate chloride intracellularly, glycine-mediated activation of chloride channels exerts a hyperpolarizing effect on plasma membrane by promoting chloride influx. In macrophages - including alveolar macrophages - hyperpolarization reduces their production of oxidants and pro-inflammatory mediators. ${ }^{187,189,190}$ However, the effect of glycine on mast cells and eosinophils does not seem to have been studied. Of particular interest is recent evidence that ASM express glycineactivated chloride channels; these induce membrane hyperpolarization in response to glycine. ${ }^{191}$ This hyperpolarization opposes calcium influx via voltage-sensitive calcium channels, and hence induces bronchodilation. When patients with cystic fibrosis were given glycine $(0.5 \mathrm{~g} / \mathrm{kg} /$ day in fluid) for 8 weeks in a double-blind crossover protocol, $\mathrm{FEV}_{1}$ increased significantly and symptom score improved significantly during supplemental glycine; no adverse effects were noted. ${ }^{192}$ Glycine is inexpensive in ample doses, has a pleasant mildly sweet flavor, and is highly and rapidly soluble, lending itself well to administration in water or other fluids; it may also be protective for vascular health. ${ }^{188}$ Hence, it may have practical potential as a bronchodilatory nutraceutical in asthma management.

It may also be noted that glycine, like cysteine, is a glutathione precursor, and appears to complement the utility of NAC for raising tissue glutathione levels. ${ }^{193}$

Limited epidemiology suggests that better magnesium (Mg) nutrition correlates with better lung function. In a random sample of over 2600 adults, dietary $\mathrm{Mg}$ was assessed by food questionnaire and lung function was assessed; after adjustment for multiple confounding variables, a $100 \mathrm{mg} /$ day increase in $\mathrm{Mg}$ intake was associated with a $27 \mathrm{~mL}$ higher FEV1, and an 18\% lesser chance of showing hyperreactivity in a methacholine challenge. ${ }^{194}$ Three placebo controlled studies of $\mathrm{Mg}$ supplementation in asthmatics, one involving exclusively children, demonstrated functional and symptomatic improvement during

Table I Proposed Nutraceutical Strategies for Controlling Asthma

\begin{tabular}{|l|l|l|}
\hline Nutraceutical & Mode of Action & Dose Range/Day \\
\hline PhyCB & Inhibit NADPH Oxidase Complexes & $100 \mathrm{mg}$ (or I5 g spirulina) \\
\hline NAC & Support Glutathione Synthesis and Expression of Antioxidant Enzymes: & $600 \mathrm{mg}, \times 2-3$ \\
\hline Lipoic Acid & & $600 \mathrm{mg}, \times 2-3$ \\
\hline Glycine & & $5-10 \mathrm{~g}, \times 2-3$ \\
\hline Selenium & & $50-100 \mathrm{mcg}$ \\
\hline Zinc & & $10-25 \mathrm{mg}, \times 2$ \\
\hline Citrulline & Support NO Biosynthesis/Bioactivity: & $2-3 \mathrm{~g}, \times 2$ \\
\hline High-Dose Folate & & $10-80 \mathrm{mg}$ \\
\hline High-Dose Biotin & & $10 \mathrm{mg}, \times 2-3$ \\
\hline NAC & Support H2S Biosynthesis: & $600 \mathrm{mg}, \times 2-3$ \\
\hline Taurine & & $1-3 \mathrm{~g}, \times 2$ \\
\hline Glycine & Dilate Bronchioles: & $5-10 \mathrm{~g}, \times 2-3$ \\
\hline Magnesium & & $100-200 \mathrm{mg}, \times 2$ \\
\hline
\end{tabular}


Mg administration; ${ }^{195-197}$ one controlled study failed to observe benefit. ${ }^{198}$

The apparent benefit of improved $\mathrm{Mg}$ status for lung function in asthma might reflect a direct impact of $\mathrm{Mg}$ on ASM hyperreactivity. Agonists which provoke ASM contraction do so, in part, by increasing intracellular free calcium; this activates the calmodulin-dependent myosin light chain kinase (MLCK), which confers a phosphorylation on myosin light chain that promotes contraction. At physiological cellular concentrations, $\mathrm{Mg}$ competes with calcium for binding to the N-terminal arm of calmodulin; binding of calcium to two sites on calmodulin is required to induce the conformational change that enables it to activate various enzymes. ${ }^{199,200}$ Activation of MLCK by calmodulin is notably less effective when calmodulin is partially Mg-bound. ${ }^{201}$ Hence, a small increase in intracellular Mg level may modestly blunt the ability of calcium influx to activate MLCK. Whether this might be the main mechanism whereby $\mathrm{Mg}$ status regulates lung function in asthmatics remains unclear.

\section{Overview}

This review suggests that nutraceutical measures which help to control lung oxidative stress (PhyCB, NAC, LA or ferulic acid, selenium and zinc), that promote bioactivity of NO (citrulline, high-dose folate, high-dose biotin) and of $\mathrm{H}_{2} \mathrm{~S}$ (NAC, taurine), and that directly induce bronchodilation via calcium modulation (glycine, $\mathrm{Mg}$ ) may have clinical potential for aiding asthma control. Table 1 summarizes these suggestions, with guesstimates as to dose ranges which might be useful. Some of these agents have never been tested even in rodent models of asthma, let alone in clinical asthma, so these proposals are still largely speculative. Nonetheless, if these agents can be shown to be of at least marginal utility, complex supplements or functional foods featuring at least several of them may have practical potential as adjuvants to current management of asthma. Owing to the fact that some of the agents of potential benefit would require bulky multigram daily doses for optimal efficacy (spirulina, citrulline, taurine, glycine), functional foods or beverages might be the most feasible way to deliver them.

\section{Abbreviations}

PhyCB, phycocyanobilin; NO, nitric oxide; H2S, hydrogen sulfide; ROCK, Rho-activated kinase; MLCP, myosin light chain phosphatase; C-PKC, protein kinase; C-PLC, phospholipase; sGC, soluble guanylate cyclase; cGMP, cyclic GMP;
G-PKG, protein kinase; ASM, airway smooth muscle; BALF, bronchoalveolar fluid; NAC, N-acetylcysteine; LA, lipoic acid; DDAH, dimethylarginine dimethylaminohydrolase; ADMA, asymmetric dimethylarginine; iNOS, inducible NO synthase; MT, Metallothionein; PDE5, phosphodiesterase 5 ; CBS, cystathionine $\beta$-synthase; CSE, cystathionine $\gamma$ lyase ; FEV1, forced expiratory volume in one second; $\mathrm{Mg}$, magnesium.

\section{Acknowledgments}

An essay entitled "Spirulina and its Chromophore Phycocyanobilin have Potential for Alleviation of Asthma“, written by Mark F. McCarty, appeared previously on the author's personal website http://catalyticlon gevity.org. A small portion of the language in the present paper was derived from that previous essay.

\section{Author Contributions}

All authors made a significant contribution to the work reported, whether that is in the conception, study design, execution, acquisition of data, analysis and interpretation, or in all these areas; took part in drafting, revising or critically reviewing the article; gave final approval of the version to be published; have agreed on the journal to which the article has been submitted; and agree to be accountable for all aspects of the work.

\section{Funding}

No funding and no grant supported this study.

\section{Disclosure}

Co-author MFM is co-inventor and co-owner of a US patent (US 8,709,434) on nutraceutical uses of phycocyanobilin oligopeptides derived from spirulina and reports a patent US 8,709,434 with royalities paid to JDS Therapeutics, Inc. JJD is an employee for Advanced Ingredients for Dietary Products. The authors report no other conflicts of interest in this work.

\section{References}

1. Fanta CH. Asthma. $N$ Engl J Med. 2009;360(10):1002-1014. doi:10.1056/NEJMra0804579

2. Bédard A, Li Z, Ait-Hadad W, et al. The role of nutritional factors in asthma: challenges and opportunities for epidemiological research. Int J Environ Res Public Health. 2021;18(6):3013. doi:10.3390/ ijerph18063013

3. Wang M, Yao Y, Jiang S, Tao F, Tang R, Sun J. How to control asthma with personalized management: where do we stand now? Curr Drug Metab. 2018;19(14):1188-1198. doi:10.2174/1389200219666180129 111810 
4. Sozańska B, Sikorska-Szaflik H. Diet modifications in primary prevention of asthma. where do we stand? Nutrients. 2021;13 (1):173. doi:10.3390/nu13010173

5. KleinJan A. Airway inflammation in asthma: key players beyond the Th2 pathway. Curr Opin Pulm Med. 2016;22(1):46-52. doi:10.1097/MCP.0000000000000224

6. Yap HM, Israf DA, Harith HH, Tham CL, Sulaiman MR. Crosstalk between signaling pathways involved in the regulation of airway smooth muscle cell hyperplasia. Front Pharmacol. 2019;10:1148. doi:10.3389/fphar.2019.01148

7. Zhang Y, Saradna A, Ratan R, et al. RhoA/Rho-kinases in asthma: from pathogenesis to therapeutic targets. Clin Transl Immunol. 2020;9(5):e01134. doi:10.1002/cti2.1134

8. Siehler S. Regulation of RhoGEF proteins by G12/13-coupled receptors. $\mathrm{Br} J$ Pharmacol. 2009;158(1):41-49. doi:10.1111/ j.1476-5381.2009.00121.x

9. Walsh MP, Susnjar M, Deng J, Sutherland C, Kiss E, Wilson DP. Phosphorylation of the protein phosphatase type 1 inhibitor protein CPI-17 by protein kinase C. Methods Mol Biol. 2007;365:209-223. doi:10.1385/1-59745-267-X:209

10. Brueggemann LI, Kakad PP, Love RB, et al. Kv7 potassium channels in airway smooth muscle cells: signal transduction intermediates and pharmacological targets for bronchodilator therapy. Am J Physiol Lung Cell Mol Physiol. 2012;302(1):L120-L132. doi:10.1152/ajplung.00194.2011

11. Haick JM, Brueggemann LI, Cribbs LL, Denning MF, Schwartz J, Byron KL. PKC-dependent regulation of Kv7.5 channels by the bronchoconstrictor histamine in human airway smooth muscle cells. Am J Physiol Lung Cell Mol Physiol. 2017;312(6):L822L834. doi:10.1152/ajplung.00567.2016

12. Ikebe M, Hartshorne DJ. Phosphorylation of smooth muscle myosin at two distinct sites by myosin light chain kinase. $J$ Biol Chem. 1985;260(18):10027-10031. doi:10.1016/S0021-9258(17) 39206-2

13. Taylor KA, Feig M, Brooks CL III, Fagnant PM, Lowey S, Trybus KM. Role of the essential light chain in the activation of smooth muscle myosin by regulatory light chain phosphorylation. $J \quad$ Struct Biol. 2014;185(3):375-382. doi:10.1016/j. jsb.2013.12.008

14. Sutcliffe A, Hollins F, Gomez E, et al. Increased nicotinamide adenine dinucleotide phosphate oxidase 4 expression mediates intrinsic airway smooth muscle hypercontractility in asthma. Am $J$ Respir Crit Care Med. 2012;185(3):267-274. doi:10.1164/ rccm.201107-12810C

15. Lu W, Kang J, Hu K, et al. The role of the Nox4-derived ROS-mediated RhoA/Rho kinase pathway in rat hypertension induced by chronic intermittent hypoxia. Sleep Breath. 2017;21 (3):667-677. doi:10.1007/s11325-016-1449-2

16. Jin L, Ying Z, Webb RC. Activation of Rho/Rho kinase signaling pathway by reactive oxygen species in rat aorta. Am J Physiol Heart Circ Physiol. 2004;287(4):H1495-H1500. doi:10.1152/ ajpheart.01006.2003

17. Jernigan NL, Walker BR, Resta TC. Reactive oxygen species mediate RhoA/Rho kinase-induced $\mathrm{Ca} 2+$ sensitization in pulmonary vascular smooth muscle following chronic hypoxia. Am J Physiol Lung Cell Mol Physiol. 2008;295(3):L515-L529. doi:10.1152/ajplung.00355.2007

18. Mahavadi S, Sriwai W, Manion O, Grider JR, Murthy KS. Diabetes-induced oxidative stress mediates upregulation of RhoA/Rho kinase pathway and hypercontractility of gastric smooth muscle. PLoS One. 2017;12(7):e0178574. doi:10.1371/ journal.pone.0178574

19. Sakai H, Suto W, Kai Y, Chiba Y. Mechanisms underlying the pathogenesis of hyper-contractility of bronchial smooth muscle in allergic asthma. J Smooth Muscle Res. 2017;53:37-47. doi:10.1540/jsmr.53.37
20. Morelli A, Filippi S, Sandner P, et al. Vardenafil modulates bladder contractility through cGMP-mediated inhibition of RhoA/Rho kinase signaling pathway in spontaneously hypertensive rats. J Sex Med. 2009;6(6):1594-1608. doi:10.1111/j.17436109.2009.01249.x

21. Aburima A, Walladbegi K, Wake JD, Naseem KM. cGMP signaling inhibits platelet shape change through regulation of the RhoA-Rho Kinase-MLC phosphatase signaling pathway. J Thromb Haemost. 2017;15(8):1668-1678. doi:10.1111/ jth. 13738

22. Nalli AD, Rajagopal S, Mahavadi S, Grider JR, Murthy KS. Inhibition of RhoA-dependent pathway and contraction by endogenous hydrogen sulfide in rabbit gastric smooth muscle cells. $\mathrm{Am}$ J Physiol Cell Physiol. 2015;308(6):C485-C495. doi:10.1152/ ajpcell.00280.2014

23. Nalli AD, Wang H, Bhattacharya S, Blakeney BA, Murthy KS. Inhibition of RhoA/Rho kinase pathway and smooth muscle contraction by hydrogen sulfide. Pharmacol Res Perspect. 2017;5(5): e00343. doi:10.1002/prp2.343

24. Zhou Z, Martin E, Sharina I, et al. Regulation of soluble guanylyl cyclase redox state by hydrogen sulfide. Pharmacol Res. 2016;111:556-562. doi:10.1016/j.phrs.2016.06.029

25. Coletta C, Papapetropoulos A, Erdelyi K, et al. Hydrogen sulfide and nitric oxide are mutually dependent in the regulation of angiogenesis and endothelium-dependent vasorelaxation. Proc Natl Acad Sci U S A. 2012;109(23):9161-9166. doi:10.1073/ pnas. 1202916109

26. Sun Y, Huang Y, Yu W, et al. Sulfhydration-associated phosphodiesterase 5A dimerization mediates vasorelaxant effect of hydrogen sulfide. Oncotarget. 2017;8(19):31888-31900. doi:10.18632/ oncotarget.16649

27. Brar SS, Kennedy TP, Whorton AR, Murphy TM, Chitano P, Hoidal JR. Requirement for reactive oxygen species in serum-induced and platelet-derived growth factor-induced growth of airway smooth muscle. J Biol Chem. 1999;274 (28):20017-20026. doi:10.1074/jbc.274.28.20017

28. Brar SS, Kennedy TP, Sturrock AB, et al. NADPH oxidase promotes NF-kappaB activation and proliferation in human airway smooth muscle. Am J Physiol Lung Cell Mol Physiol. 2002;282(4):L782-L795. doi:10.1152/ajplung.00206.2001

29. Sturrock A, Huecksteadt TP, Norman K, et al. Nox4 mediates TGF-beta1-induced retinoblastoma protein phosphorylation, proliferation, and hypertrophy in human airway smooth muscle cells. Am J Physiol Lung Cell Mol Physiol. 2007;292(6):L1543-L1555. doi:10.1152/ajplung.00430.2006

30. Thomas B, Rutman A, Hirst RA, et al. Ciliary dysfunction and ultrastructural abnormalities are features of severe asthma. J Allergy Clin Immunol. 2010;126(4):722-729. doi:10.1016/j. jaci.2010.05.046

31. Wan WY, Hollins F, Haste L, et al. NADPH Oxidase-4 overexpression is associated with epithelial ciliary dysfunction in neutrophilic asthma. Chest. 2016;149(6):1445-1459. doi:10.1016/j.chest.2016.01.024

32. Uhm TG, Kim BS, Chung IY. Eosinophil development, regulation of eosinophil-specific genes, and role of eosinophils in the pathogenesis of asthma. Allergy Asthma Immunol Res. 2012;4 (2):68-79. doi:10.4168/aair.2012.4.2.68

33. Chin JE, Hatfield CA, Winterrowd GE, et al. Airway recruitment of leukocytes in mice is dependent on alpha4-integrins and vascular cell adhesion molecule-1. Am J Physiol. 1997;272(2 Pt 1): L219-L229. doi:10.1152/ajplung.1997.272.2.L219

34. Sagara H, Matsuda H, Wada N, et al. A monoclonal antibody against very late activation antigen-4 inhibits eosinophil accumulation and late asthmatic response in a guinea pig model of asthma. Int Arch Allergy Immunol. 1997;112(3):287-294. doi:10.1159/000237468 
35. Matheny HE, Deem TL, Cook-Mills JM. Lymphocyte migration through monolayers of endothelial cell lines involves VCAM-1 signaling via endothelial cell $\mathrm{NADPH}$ oxidase. J Immunol. 2000;164(12):6550-6559. doi:10.4049/jimmunol.164.12.6550

36. Deem TL, Cook-Mills JM. Vascular cell adhesion molecule 1 (VCAM-1) activation of endothelial cell matrix metalloproteinases: role of reactive oxygen species. Blood. 2004;104 (8):2385-2393. doi:10.1182/blood-2004-02-0665

37. Abdala-Valencia H, Earwood J, Bansal S, et al. Nonhematopoietic $\mathrm{NADPH}$ oxidase regulation of lung eosinophilia and airway hyperresponsiveness in experimentally induced asthma. Am J Physiol Lung Cell Mol Physiol. 2007;292(5):L1111-L1125. doi:10.1152/ajplung.00208.2006

38. Suzuki Y, Yoshimaru T, Inoue T, Niide O, Ra C. Role of oxidants in mast cell activation. Chem Immunol Allergy. 2005;87:32-42.

39. Inoue T, Suzuki Y, Yoshimaru T, Ra C. Reactive oxygen species produced up- or downstream of calcium influx regulate proinflammatory mediator release from mast cells: role of NADPH oxidase and mitochondria. Biochim Biophys Acta. 2008;1783 (5):789-802. doi:10.1016/j.bbamcr.2007.12.004

40. Cho KJ, Seo JM, Lee MG, Kim JH. BLT2 Is upregulated in allergen-stimulated mast cells and mediates the synthesis of Th2 cytokines. J Immunol. 2010;185(10):6329-6337. doi:10.4049/ jimmunol.1001213

41. Kim SY, Moon KA, Jo HY, et al. Anti-inflammatory effects of apocynin, an inhibitor of NADPH oxidase, in airway inflammation. Immunol Cell Biol. 2012;90(4):441-448. doi:10.1038/icb.2011.60

42. Peters EA, Hiltermann JT, Stolk J. Effect of apocynin on ozone-induced airway hyperresponsiveness to methacholine in asthmatics. Free Radic Biol Med. 2001;31(11):1442-1447. doi:10.1016/S0891-5849(01)00725-0

43. Lanone $\mathrm{S}$, Bloc S, Foresti R, et al. Bilirubin decreases nos2 expression via inhibition of $\mathrm{NAD}(\mathrm{P}) \mathrm{H}$ oxidase: implications for protection against endotoxic shock in rats. FASEB J. 2005;19 (13):1890-1892. doi:10.1096/fj.04-2368fje

44. Matsumoto H, Ishikawa K, Itabe H, Maruyama Y. Carbon monoxide and bilirubin from heme oxygenase-1 suppresses reactive oxygen species generation and plasminogen activator inhibitor-1 induction. Mol Cell Biochem. 2006;291(1-2):21-28. doi:10.1007/ s11010-006-9190-y

45. Jiang F, Roberts SJ, Datla S, Dusting GJ. NO modulates NADPH oxidase function via heme oxygenase-1 in human endothelial cells. Hypertension. 2006;48(5):950-957. doi:10.1161/01. HYP.0000242336.58387.1f

46. Datla SR, Dusting GJ, Mori TA, Taylor CJ, Croft KD, Jiang F. Induction of heme oxygenase-1 in vivo suppresses NADPH oxidase derived oxidative stress. Hypertension. 2007;50(4):636-642. doi:10.1161/HYPERTENSIONAHA.107.092296

47. Ohrui T, Yasuda H, Yamaya M, Matsui T, Sasaki H. Transient relief of asthma symptoms during jaundice: a possible beneficial role of bilirubin. Tohoku J Exp Med. 2003;199(3):193-196. doi:10.1620/tjem.199.193

48. Kim DE, Lee Y, Kim M, Lee S, Jon S, Lee SH. Bilirubin nanoparticles ameliorate allergic lung inflammation in a mouse model of asthma. Biomaterials. 2017;140:37-44. doi:10.1016/j. biomaterials.2017.06.014

49. Keshavan P, Deem TL, Schwemberger SJ, Babcock GF, CookMills JM, Zucker SD. Unconjugated bilirubin inhibits VCAM-1-mediated transendothelial leukocyte migration. J Immunol. 2005;174(6):3709-3718. doi:10.4049/ jimmunol.174.6.3709

50. Samb A, Taille C, Almolki A, et al. Heme oxygenase modulates oxidant-signaled airway smooth muscle contractility: role of bilirubin. Am J Physiol Lung Cell Mol Physiol. 2002;283(3): L596-L603. doi:10.1152/ajplung.00446.2001
51. Taille C, Almolki A, Benhamed M, et al. Heme oxygenase inhibits human airway smooth muscle proliferation via a bilirubin-dependent modulation of ERK1/2 phosphorylation. $J$ Biol Chem. 2003;278(29):27160-27168. doi:10.1074/jbc. M300364200

52. Takamiya R, Murakami M, Kajimura M, et al. Stabilization of mast cells by heme oxygenase-1: an anti-inflammatory role. $\mathrm{Am}$ $J$ Physiol Heart Circ Physiol. 2002;283(3):H861-H870. doi:10.1152/ajpheart.00740.2001

53. Matsushima M, Takagi K, Ogawa M, et al. Heme oxygenase-1 mediates the anti-allergic actions of quercetin in rodent mast cells. Inflamm Res. 2009;58(10):705-715. doi:10.1007/s00011-0090039-1

54. McCarty MF. Clinical potential of Spirulina as a source of phycocyanobilin. $J$ Med Food. 2007;10(4):566-570. doi:10.1089/jmf.2007.621

55. Terry MJ, Maines MD, Lagarias JC. Inactivation of phytochromeand phycobiliprotein-chromophore precursors by rat liver biliverdin reductase. $J$ Biol Chem. 1993;268(35):26099-26106. doi:10.1016/S0021-9258(19)74286-0

56. Zheng J, Inoguchi T, Sasaki S, et al. Phycocyanin and phycocyanobilin from spirulina platensis protect against diabetic nephropathy by inhibiting oxidative stress. Am J Physiol Regul Integr Comp Physiol. 2013;304:R110-R120. doi:10.1152/ ajpregu.00648.2011

57. Romay C, Gonzalez R, Ledon N, Remirez D, Rimbau V. C-phycocyanin: a biliprotein with antioxidant, anti-inflammatory and neuroprotective effects. Curr Protein Pept Sci. 2003;4 (3):207-216. doi:10.2174/1389203033487216

58. Riss J, Décordé K, Sutra T, et al. Phycobiliprotein C-phycocyanin from spirulina platensis is powerfully responsible for reducing oxidative stress and NADPH oxidase expression induced by an atherogenic diet in hamsters. J Agric Food Chem. 2007;55 (19):7962-7967. doi:10.1021/jf070529g

59. Labhe RU, Mani UV, Iyer UM, Mishra M, Jani K, Bhattacharya A. The effect of spirulina in the treatment of bronchial asthma. $J$ Nutraceuticals Func Med Foods. 2015;3 (4):53-60. doi:10.1300/J133v03n04_06

60. Horsfall LJ, Rait G, Walters K, et al. Serum bilirubin and risk of respiratory disease and death. JAMA. 2011;305(7):691-697. doi:10.1001/jama.2011.124

61. Wang HD, Yamaya M, Okinaga S, et al. Bilirubin ameliorates bleomycin-induced pulmonary fibrosis in rats. Am J Respir Crit Care Med. 2002;165(3):406-411. doi:10.1164/ajrccm.165.3.2003149

62. Ohrui T, Higuchi M, Kanda A, Matsui T, Sato E, Sasaki H. A patient with exacerbation of idiopathic pulmonary fibrosis which was resolved probably due to the coexisting hyperbilirubinemia? Tohoku J Exp Med. 2001;193(3):245-249. doi:10.1620/tjem.193.245

63. Waypa GB, Guzy R, Mungai PT, et al. Increases in mitochondrial reactive oxygen species trigger hypoxia-induced calcium responses in pulmonary artery smooth muscle cells. Circ Res. 2006;99(9):970-978. doi:10.1161/01.RES.0000247068.75808.3f

64. Rathore R, Zheng YM, Niu CF, et al. Hypoxia activates NADPH oxidase to increase [ROS]i and [Ca2+]i through the mitochondrial ROS-PKCepsilon signaling axis in pulmonary artery smooth muscle cells. Free Radic Biol Med. 2008;45(9):1223-1231. doi:10.1016/j.freeradbiomed.2008.06.012

65. Wang YX, Zheng YM. ROS-dependent signaling mechanisms for hypoxic $\mathrm{Ca}(2+)$ responses in pulmonary artery myocytes. Antioxid Redox Signal. 2010;12(5):611-623. doi:10.1089/ ars.2009.2877

66. McCarty MF, Barroso-Aranda J, Contreras F. Practical strategies for targeting NF-kappaB and NADPH oxidase may improve survival during lethal influenza epidemics. Med Hypotheses. 2010;74(1):18-20. doi:10.1016/j.mehy.2009.04.052 
67. Vlahos R, Stambas J, Bozinovski S, Broughton BR, Drummond GR, Selemidis S. Inhibition of Nox2 oxidase activity ameliorates influenza A virus-induced lung inflammation. PLoS Pathog. 2011;7(2):e1001271. doi:10.1371/journal.ppat.1001271

68. Vlahos R, Stambas J, Selemidis S. Suppressing production of reactive oxygen species (ROS) for influenza A virus therapy. Trends Pharmacol Sci. 2012;33(1):3-8. doi:10.1016/j. tips.2011.09.001

69. Sarady-Andrews JK, Liu F, Gallo D, et al. Biliverdin administration protects against endotoxin-induced acute lung injury in rats. Am J Physiol Lung Cell Mol Physiol. 2005;289(6):L1131-L1137. doi:10.1152/ajplung.00458.2004

70. Pongnimitprasert N, El-Benna J, Foglietti MJ, GougerotPocidalo MA, Bernard M, Braut-Boucher F. Potential role of the "NADPH oxidases" (NOX/DUOX) family in cystic fibrosis. Ann Biol Clin (Paris). 2008;66(6):621-629. doi:10.1684/ abc. 2008.0285

71. McCarty MF Novel prospects for managing cystic fibrosis. Ref Type: Unpublished Work; 2012.

72. Mao TK, Van de Water J, Gershwin ME. Effects of a Spirulina-based dietary supplement on cytokine production from allergic rhinitis patients. $J$ Med Food. 2005;8(1):27-30. doi:10.1089/jmf.2005.8.27

73. PentÃn-Rol G, MartÃ-nez-SÃ $i n c h e z ~ G$, Cervantes-Llanos M, et al. C-Phycocyanin ameliorates experimental autoimmune encephalomyelitis and induces regulatory $\mathrm{T}$ cells. Int Immunopharmacol. 2011;11(1):29-38. doi:10.1016/j. intimp.2010.10.001

74. McCarty MF. Clinical potential of phycocyanobilin for induction of $\mathrm{T}$ regulatory cells in the management of inflammatory disorders. Med Hypotheses. 2011;77(6):1031-1033. doi:10.1016/ j.mehy.2011.08.041

75. Basdeo SA, Campbell NK, Sullivan LM, et al. Suppression of human alloreactive TÂ cells by linear tetrapyrroles; relevance for transplantation. Transl Res. 2016;178:81-94. doi:10.1016/j. trs1.2016.07.011

76. Gandhi R, Kumar D, Burns EJ, et al. Activation of the aryl hydrocarbon receptor induces human type 1 regulatory $\mathrm{T}$ cell-like and Foxp3(+) regulatory T cells. Nat Immunol. 2010;11 (9):846-853. doi:10.1038/ni.1915

77. Phelan D, Winter GM, Rogers WJ, Lam JC, Denison MS. Activation of the Ah receptor signal transduction pathway by bilirubin and biliverdin. Arch Biochem Biophys. 1998;357 (1):155-163. doi:10.1006/abbi.1998.0814

78. Vã-tek L. Bilirubin as a signaling molecule. Med Res Rev. 2020;40(4):1335-1351. doi:10.1002/med.21660

79. Bindoli A, Rigobello MP. Principles in redox signaling: from chemistry to functional significance. Antioxid Redox Signal. 2013;18(13):1557-1593. doi:10.1089/ars.2012.4655

80. Lo CM, Carroll KS. The redox biochemistry of protein sulfenylation and sulfinylation. J Biol Chem. 2013;288(37):26480-26488. doi:10.1074/jbc.R113.467738

81. Dickinson DA, Forman HJ. Glutathione in defense and signaling: lessons from a small thiol. Ann N Y Acad Sci. 2002;973:488-504. doi:10.1111/j.1749-6632.2002.tb04690.x

82. Shelton MD, Chock PB, Mieyal JJ. Glutaredoxin: role in reversible protein s-glutathionylation and regulation of redox signal transduction and protein translocation. Antioxid Redox Signal. 2005;7(3-4):348-366. doi:10.1089/ars.2005.7.348

83. Parsons ZD, Gates KS. Thiol-dependent recovery of catalytic activity from oxidized protein tyrosine phosphatases. Biochemistry. 2013;52(37):6412-6423. doi:10.1021/bi400451m

84. Atkuri KR, Mantovani JJ, Herzenberg LA, Herzenberg LA. N-Acetylcysteine-a safe antidote for cysteine/glutathione deficiency. Curr Opin Pharmacol. 2007;7(4):355-359. doi:10.1016/ j.coph.2007.04.005
85. Dodd S, Dean O, Copolov DL, Malhi GS, Berk M. $\mathrm{N}$-acetylcysteine for antioxidant therapy: pharmacology and clinical utility. Expert Opin Biol Ther. 2008;8(12):1955-1962. doi:10.1517/14728220802517901

86. Blesa S, Cortijo J, Mata M, et al. Oral N-acetylcysteine attenuates the rat pulmonary inflammatory response to antigen. Eur Respir J. 2003;21(3):394-400. doi:10.1183/09031936.03.00039602

87. Blesa S, Cortijo J, Martinez-Losa M, et al. Effectiveness of oral N acetylcysteine in a rat experimental model of asthma. Pharmacol Res. 2002;45(2):135-140. doi:10.1006/phrs.2001.0917

88. Eftekhari P, Hajizadeh S, Raoufy MR, et al. Preventive effect of $\mathrm{N}$-acetylcysteine in a mouse model of steroid resistant acute exacerbation of asthma. EXCLI J. 2013;12:184-192.

89. Carlsten C, MacNutt MJ, Zhang Z, Sava F, Pui MM. Anti-oxidant $\mathrm{N}$-acetylcysteine diminishes diesel exhaust-induced increased airway responsiveness in person with airway hyper-reactivity. Toxicol Sci. 2014;139(2):479-487.

90. Aliyali M, Poorhasan AA, Sharifpoor A, Zalli F. Effects of $\mathrm{N}$-acetylcysteine on asthma exacerbation. Iran J Allergy Asthma Immunol. 2010;9(2):103-109.

91. Wild AC, Moinova HR, Mulcahy RT. Regulation of gamma-glutamylcysteine synthetase subunit gene expression by the transcription factor Nrf2. J Biol Chem. 1999;274 (47):33627-33636. doi:10.1074/jbc.274.47.33627

92. Suh JH, Shenvi SV, Dixon BM, et al. Decline in transcriptional activity of Nrf2 causes age-related loss of glutathione synthesis, which is reversible with lipoic acid. Proc Natl Acad Sci USA. 2004;101(10):3381-3386. doi:10.1073/pnas.0400282101

93. Papanas N, Ziegler D. Efficacy of alpha-lipoic acid in diabetic neuropathy. Expert Opin Pharmacother. 2014;15(18):2721-2731. doi:10.1517/14656566.2014.972935

94. Cho YS, Lee J, Lee TH, et al. Alpha-Lipoic acid inhibits airway inflammation and hyperresponsiveness in a mouse model of asthma. $J$ Allergy Clin Immunol. 2004;114(2):429-435. doi:10.1016/j.jaci.2004.04.004

95. Park SJ, Lee KS, Lee SJ, et al. L-2-Oxothiazolidine-4-carboxylic acid or alpha-lipoic acid attenuates airway remodeling: involvement of nuclear factor-kappaB (NF-kappaB), nuclear factor erythroid 2p45-related factor-2 (Nrf2), and hypoxia-inducible factor (HIF). Int J Mol Sci. 2012;13(7):7915-7937. doi:10.3390/ ijms 13077915

96. Lee CC, Wang CC, Huang HM, Lin CL, Leu SJ, Lee YL. Ferulic acid induces Th1 responses by modulating the function of dendritic cells and ameliorates Th2-mediated allergic airway inflammation in mice. Evid Based Complement Alternat Med. 2015;2015:678487. doi:10.1155/2015/678487

97. Sin Singer BA, Carvalho Gouveia AC, de Souza Alves CC, et al. Ferulic acid supresses Th2 immune response and prevents remodeling in ovalbumin-induced pulmonary allergy associated with inhibition of epithelial-derived cytokines. Pulm Pharmacol Ther. 2017;45:202-209. doi:10.1016/j.pupt.2017.07.001

98. Alam J, Stewart D, Touchard C, Boinapally S, Choi AM, Cook JL. Nrf2, a Cap'n'Collar transcription factor, regulates induction of the heme oxygenase-1 gene. $J$ Biol Chem. 1999;274(37):26071-26078. doi:10.1074/jbc.274.37.26071

99. Allan CB, Lacourciere GM, Stadtman TC. Responsiveness of selenoproteins to dietary selenium. Annu Rev Nutr. 1999;19:1-16. doi:10.1146/annurev.nutr.19.1.1

100. Chen M, Sun Y, Wu Y. Lower circulating zinc and selenium levels are associated with an increased risk of asthma: evidence from a meta-analysis. Public Health Nutr. 2020;23(9):1555-1562. doi:10.1017/S1368980019003021

101. Dupont LL, Glynos C, Bracke KR, Brouckaert P, Brusselle GG. Role of the nitric oxide-soluble guanylyl cyclase pathway in obstructive airway diseases. Pulm Pharmacol Ther. 2014;29 (1):1-6. doi:10.1016/j.pupt.2014.07.004 
102. Ellis JL. Role of soluble guanylyl cyclase in the relaxations to a nitric oxide donor and to nonadrenergic nerve stimulation in guinea pig trachea and human bronchus. J Pharmacol Exp Ther. 1997;280(3):1215-1218.

103. Hamad AM, Johnson SR, Knox AJ. Antiproliferative effects of NO and ANP in cultured human airway smooth muscle. Am $J$ Physiol. 1999;277(5 Pt 1):L910-L918. doi:10.1152/ ajplung.1999.277.5.L910

104. Yu H, Payne TJ, Mohanty DK. Effects of slow, sustained, and rate-tunable nitric oxide donors on human aortic smooth muscle cells proliferation. Chem Biol Drug Des. 2011;78(4):527-534. doi:10.1111/j.1747-0285.2011.01174.x

105. Jain B, Rubinstein I, Robbins RA, Leise KL, Sisson JH. Modulation of airway epithelial cell ciliary beat frequency by nitric oxide. Biochem Biophys Res Commun. 1993;191 (1):83-88. doi:10.1006/bbrc.1993.1187

106. Tamaoki J, Kondo M, Tagaya E, Takemura K, Konno K. Zizyphi fructus, a constituent of antiasthmatic herbal medicine, stimulates airway epithelial ciliary motility through nitric oxide generation. Exp Lung Res. 1996;22(3):255-266. doi:10.3109/ 01902149609031774

107. Ten BR, De CR, Van HR, et al. Overexpression of endothelial nitric oxide synthase suppresses features of allergic asthma in mice. Respir Res. 2006;7:58. doi:10.1186/1465-9921-7-58

108. Kobayashi K, Nishimura Y, Yamashita T, Nishiuma T, Satouchi M, Yokoyama M. The effect of overexpression of endothelial nitric oxide synthase on eosinophilic lung inflammation in a murine model. Int Immunopharmacol. 2006;6 (7):1040-1052. doi:10.1016/j.intimp.2005.09.016

109. Thomazzi SM, Moreira J, Marcondes S, Nucci GD, Antunes E. Role of cyclic GMP on inhibition by nitric oxide donors of human eosinophil chemotaxis in vitro. $B r J$ Pharmacol. 2004;141 (4):653-660. doi:10.1038/sj.bjp.0705661

110. Baldissera L Jr, Squebola-Cola DM, Calixto MC, et al. The soluble guanylyl cyclase activator BAY 60-2770 inhibits murine allergic airways inflammation and human eosinophil chemotaxis. Pulm Pharmacol Ther. 2016;41:86-95. doi:10.1016/j. pupt.2016.11.001

111. Tawa M, Shimosato $T$, Iwasaki $H$, Imamura $T$, Okamura $T$. Effects of peroxynitrite on relaxation through the $\mathrm{NO} / \mathrm{sGC}$ / cGMP pathway in isolated rat iliac arteries. J Vasc Res. 2014;51 (6):439-446. doi:10.1159/000371491

112. Milstien S, Katusic Z. Oxidation of tetrahydrobiopterin by peroxynitrite: implications for vascular endothelial function. Biochem Biophys Res Commun. 1999;263(3):681-684. doi:10.1006/ bbrc.1999.1422

113. Pope AJ, Druhan L, Guzman JE, et al. Role of DDAH-1 in lipid peroxidation product-mediated inhibition of endothelial NO generation. Am J Physiol Cell Physiol. 2007;293(5):C1679C1686. doi:10.1152/ajpcell.00224.2007

114. McCarty MF. Asymmetric dimethylarginine is a well established mediating risk factor for cardiovascular morbidity and mortality-should patients with elevated levels be supplemented with citrulline? Healthcare (Basel). 2016;4(3):40. doi:10.3390/ healthcare4030040

115. Kinker KG, Gibson AM, Bass SA, et al. Overexpression of dimethylarginine dimethylaminohydrolase 1 attenuates airway inflammation in a mouse model of asthma. PLoS One. 2014;9 (1):e85148. doi:10.1371/journal.pone.0085148

116. Alving K, Weitzberg E, Lundberg JM. Increased amount of nitric oxide in exhaled air of asthmatics. Eur Respir J. 1993;6 (9):1368-1370.

117. Persson MG, Zetterstrom O, Agrenius V, Ihre E, Gustafsson LE. Single-breath nitric oxide measurements in asthmatic patients and smokers. Lancet. 1994;343(8890):146-147. doi:10.1016/S01406736(94)90935-0
118. Brindicci C, Ito K, Barnes PJ, Kharitonov SA. Effect of an inducible nitric oxide synthase inhibitor on differential flow-exhaled nitric oxide in asthmatic patients and healthy volunteers. Chest. 2007;132(2):581-588. doi:10.1378/chest.063046

119. Ansarin K, Chatkin JM, Ferreira IM, Gutierrez CA, Zamel N, Chapman KR. Exhaled nitric oxide in chronic obstructive pulmonary disease: relationship to pulmonary function. Eur Respir J. 2001;17(5):934-938. doi:10.1183/09031936.01.17509340

120. Papapetropoulos A, Simoes DC, Xanthou G, Roussos C, Gratziou C. Soluble guanylyl cyclase expression is reduced in allergic asthma. Am J Physiol Lung Cell Mol Physiol. 2006;290 (1):L179-L184. doi:10.1152/ajplung.00330.2005

121. Placeres-Uray F, De alfonzo RG, Lippo dB I, Alfonzo MJ. Soluble guanylyl cyclase is reduced in airway smooth muscle cells from a murine model of allergic asthma. World Allergy Organ J. 2010;3(12):271-276. doi:10.1097/ WOX.0b013e318201d80b

122. Tajti G, Papp C, Kardos L, et al. Positive correlation of airway resistance and serum asymmetric dimethylarginine (ADMA) in bronchial asthma patients lacking evidence for systemic inflammation. Allergy Asthma Clin Immunol. 2018;14:2. doi:10.1186/s13223-017-0226-5

123. Carraro S, Giordano G, Piacentini G, et al. Asymmetric dimethylarginine in exhaled breath condensate and serum of children with asthma. Chest. 2013;144(2):405-410. doi:10.1378/chest.12-2379

124. Holguin F, Comhair SA, Hazen SL, et al. An association between L-arginine/asymmetric dimethyl arginine balance, obesity, and the age of asthma onset phenotype. Am J Respir Crit Care Med. 2013;187(2):153-159. doi:10.1164/rccm.201207-1270OC

125. Scott JA, North ML, Rafii M, et al. Asymmetric dimethylarginine is increased in asthma. Am J Respir Crit Care Med. 2011;184 (7):779-785. doi:10.1164/rccm.201011-18100C

126. Holguin F. Arginine and nitric oxide pathways in obesity-associated asthma. J Allergy (Cairo). 2013;2013:714595. doi:10.1155/2013/714595

127. Waugh WH, Daeschner CW III, Files BA, McConnell ME, Strandjord SE. Oral citrulline as arginine precursor may be beneficial in sickle cell disease: early phase two results. $J$ Natl Med Assoc. 2001;93(10):363-371.

128. Schwedhelm E, Maas R, Freese R, et al. Pharmacokinetic and pharmacodynamic properties of oral L-citrulline and L-arginine: impact on nitric oxide metabolism. Br J Clin Pharmacol. 2008;65 (1):51-59. doi:10.1111/j.1365-2125.2007.02990.x

129. Winnica D, Que LG, Baffi C, et al. 1-citrulline prevents asymmetric dimethylarginine-mediated reductions in nitric oxide and nitrosative stress in primary human airway epithelial cells. Clin Exp Allergy. 2017;47(2):190-199. doi:10.1111/cea.12802

130. Romero MJ, Platt DH, Caldwell RB, Caldwell RW. Therapeutic use of citrulline in cardiovascular disease. Cardiovasc Drug Rev. 2006;24(3-4):275-290. doi:10.1111/j.1527-3466.2006.00275.x

131. Mabalirajan U, Ahmad T, Leishangthem GD, et al. Beneficial effects of high dose of L-arginine on airway hyperresponsiveness and airway inflammation in a murine model of asthma. J Allergy Clin Immunol. 2010;125(3):626-635. doi:10.1016/j. jaci.2009.10.065

132. Zhang R, Kubo M, Murakami I, et al. 1-Arginine administration attenuates airway inflammation by altering 1-arginine metabolism in an NC/Nga mouse model of asthma. J Clin Biochem Nutr. 2015;56(3):201-207. doi:10.3164/jcbn.14-140

133. Al Qadi-Nassar B, Bichon-Laurent F, Portet K, Tramini P, Arnoux B, Michel A. Effects of L-arginine and phosphodiesterase-5 inhibitor, sildenafil, on inflammation and airway responsiveness of sensitized BP2 mice. Fundam Clin Pharmacol. 2007;21(6):611-620. doi:10.1111/j.14728206.2007.00523.x 
134. Arikan-Ayyildiz Z, Karaman M, Firinci F, et al. Effects of inhaled L-arginine administration in a murine model of acute asthma. Iran J Allergy Asthma Immunol. 2014;13(5):317-323.

135. Takano H, Lim HB, Miyabara Y, Ichinose T, Yoshikawa T, Sagai M. Oral administration of L-arginine potentiates allergen-induced airway inflammation and expression of interleukin-5 in mice. $J$ Pharmacol Exp Ther. 1998;286 (2):767-771.

136. Klein E, Weigel J, Buford MC, Holian A, Wells SM. Asymmetric dimethylarginine potentiates lung inflammation in a mouse model of allergic asthma. Am J Physiol Lung Cell Mol Physiol. 2010;299 (6):L816-L825. doi:10.1152/ajplung.00188.2010

137. Holguin F, Grasemann H, Sharma S, et al. L-Citrulline increases nitric oxide and improves control in obese asthmatics. JCI Insight. 2019;4(24):e131733. doi:10.1172/jci.insight.131733

138. Asagami T, Abbasi F, Stuelinger M, et al. Metformin treatment lowers asymmetric dimethylarginine concentrations in patients with type 2 diabetes. Metabolism. 2002;51(7):843-846. doi:10.1053/meta.2002.33349

139. Chen CZ, Hsu CH, Li CY, Hsiue TR. Insulin use increases risk of asthma but metformin use reduces the risk in patients with diabetes in a Taiwanese population cohort. J Asthma. 2017;54 (10):1019-1025. doi:10.1080/02770903.2017.1283698

140. Li CY, Erickson SR, Wu CH. Metformin use and asthma outcomes among patients with concurrent asthma and diabetes. Respirology. 2016;21(7):1210-1218. doi:10.1111/resp.12818

141. Li Z, Zheng J, Zhang N, Li C. Berberine improves airway inflammation and inhibits NF-kappaB signaling pathway in an ovalbumin-induced rat model of asthma. J Asthma. 2016;53 (10):999-1005. doi:10.1080/02770903.2016.1180530

142. McCarty MF. Oster rediscovered-mega-dose folate for symptomatic atherosclerosis. Med Hypotheses. 2007;69(2):325-332. doi:10.1016/j.mehy.2004.11.049

143. Moens AL, Claeys MJ, Wuyts FL, et al. Effect of folic acid on endothelial function following acute myocardial infarction. $\mathrm{Am}$ J Cardiol. 2007;99(4):476-481. doi:10.1016/j. amjcard.2006.08.057

144. Moens AL, Vrints CJ, Claeys MJ, Timmermans JP, Champion HC, Kass DA. Mechanisms and potential therapeutic targets for folic acid in cardiovascular disease. Am J Physiol Heart Circ Physiol. 2008;294(5):H1971-H1977. doi:10.1152/ ajpheart.91503.2007

145. Tawakol A, Migrino RQ, Aziz KS, et al. High-dose folic acid acutely improves coronary vasodilator function in patients with coronary artery disease. J Am Coll Cardiol. 2005;45 (10):1580-1584. doi:10.1016/j.jacc.2005.02.038

146. Rezk BM, Haenen GR, van der Vijgh WJ, Bast A. Tetrahydrofolate and 5-methyltetrahydrofolate are folates with high antioxidant activity. Identification of the antioxidant pharmacophore. FEBS Lett. 2003;555(3):601-605. doi:10.1016/ S0014-5793(03)01358-9

147. Crabtree MJ, Hale AB, Channon KM. Dihydrofolate reductase protects endothelial nitric oxide synthase from uncoupling in tetrahydrobiopterin deficiency. Free Radic Biol Med. 2011;50 (11):1639-1646. doi:10.1016/j.freeradbiomed.2011.03.010

148. Gao L, Siu KL, Chalupsky K, et al. Role of uncoupled endothelial nitric oxide synthase in abdominal aortic aneurysm formation: treatment with folic acid. Hypertension. 2012;59(1):158-166. doi:10.1161/HYPERTENSIONAHA.111.181644

149. Siu KL, Miao XN, Cai H. Recoupling of eNOS with folic acid prevents abdominal aortic aneurysm formation in angiotensin II-infused apolipoprotein E null mice. PLoS One. 2014;9(2): e88899. doi:10.1371/journal.pone.0088899
150. Chalupsky K, Kracun D, Kanchev I, Bertram K, Gorlach A. Folic acid promotes recycling of tetrahydrobiopterin and protects against hypoxia-induced pulmonary hypertension by recoupling endothelial nitric oxide synthase. Antioxid Redox Signal. 2015;23 (14):1076-1091. doi:10.1089/ars.2015.6329

151. Sharma SK, Ebadi M. Metallothionein attenuates 3-morpholinosydnonimine (SIN-1)-induced oxidative stress in dopaminergic neurons. Antioxid Redox Signal. 2003;5 (3):251-264. doi:10.1089/152308603322110832

152. Cai L, Klein JB, Kang YJ. Metallothionein inhibits peroxynitrite-induced DNA and lipoprotein damage. $J$ Biol Chem. 2000;275(50):38957-38960. doi:10.1074/jbc.C000593200

153. Inoue $\mathrm{K}$, Takano H, Yanagisawa R, et al. Role of metallothionein in antigen-related airway inflammation. Exp Biol Med (Maywood). 2005;230(1):75-81. doi:10.1177/ 153537020523000110

154. Sullivan VK, Burnett FR, Cousins RJ. Metallothionein expression is increased in monocytes and erythrocytes of young men during zinc supplementation. J Nutr. 1998;128(4):707-713. doi:10.1093/ jn/128.4.707

155. Cao J, Cousins RJ. Metallothionein mRNA in monocytes and peripheral blood mononuclear cells and in cells from dried blood spots increases after zinc supplementation of men. J Nutr. 2000;130(9):2180-2187. doi:10.1093/jn/130.9.2180

156. Rerksuppaphol S, Rerksuppaphol L. Zinc supplementation in children with asthma exacerbation. Pediatr Rep. 2016;8(4):6685. doi: $10.4081 /$ pr.2016.6685

157. Ghaffari J, Khalilian A, Salehifar E, Khorasani E, Rezaii MS. Effect of zinc supplementation in children with asthma: a randomized, placebo-controlled trial in northern Islamic Republic of Iran. East Mediterr Health J. 2014;20(6):391-396. doi:10.26719/2014.20.6.391

158. Morgan CI, Ledford JR, Zhou P, Page K. Zinc supplementation alters airway inflammation and airway hyperresponsiveness to a common allergen. J Inflamm (Lond). 2011;8:36. doi:10.1186/ 1476-9255-8-36

159. Lang C, Murgia C, Leong M, et al. Anti-inflammatory effects of zinc and alterations in zinc transporter mRNA in mouse models of allergic inflammation. Am J Physiol Lung Cell Mol Physiol. 2007;292(2):L577-L584. doi:10.1152/ajplung.00280.2006

160. Szabo C. Hydrogen sulfide, an enhancer of vascular nitric oxide signaling: mechanisms and implications. Am J Physiol Cell Physiol. 2017;312(1):C3-C15. doi:10.1152/ajpcell.00282.2016

161. Nalli AD, Bhattacharya S, Wang H, Kendig DM, Grider JR, Murthy KS. Augmentation of cGMP/PKG pathway and colonic motility by hydrogen sulfide. Am J Physiol Gastrointest Liver Physiol. 2017;313(4):G330-G341. doi:10.1152/ajpgi.00161.2017

162. Wang $\mathrm{P}$, Zhang $\mathrm{G}$, Wondimu $\mathrm{T}$, Ross B, Wang R. Hydrogen sulfide and asthma. Exp Physiol. 2011;96(9):847-852. doi:10.1113/expphysiol.2011.057448

163. Wu R, Yao WZ, Chen YH, Geng B, Tang CS. [Plasma level of endogenous hydrogen sulfide in patients with acute asthma]. Beijing Da Xue Xue Bao Yi Xue Ban. 2008;40(5):505-508. (Chinese).

164. Chen YH, Wu R, Geng B, et al. Endogenous hydrogen sulfide reduces airway inflammation and remodeling in a rat model of asthma. Cytokine. 2009;45(2):117-123. doi:10.1016/j.cyto.2008.11.009

165. Chen YH, Wang PP, Wang XM, et al. Involvement of endogenous hydrogen sulfide in cigarette smoke-induced changes in airway responsiveness and inflammation of rat lung. Cytokine. 2011;53 (3):334-341. doi:10.1016/j.cyto.2010.12.006

166. Perry MM, Hui CK, Whiteman M, et al. Hydrogen sulfide inhibits proliferation and release of IL-8 from human airway smooth muscle cells. Am J Respir Cell Mol Biol. 2011;45(4):746-752. doi:10.1165/rcmb.2010-0304OC 
167. Roviezzo F, Bertolino A, Sorrentino R, et al. Hydrogen sulfide inhalation ameliorates allergen induced airway hypereactivity by modulating mast cell activation. Pharmacol Res. 2015;100:85-92. doi:10.1016/j.phrs.2015.07.032

168. Rodrigues L, Ekundi-Valentim E, Florenzano J, et al. Protective effects of exogenous and endogenous hydrogen sulfide in mast cell-mediated pruritus and cutaneous acute inflammation in mice. Pharmacol Res. 2017;115:255-266. doi:10.1016/j. phrs.2016.11.006

169. Zhang G, Wang P, Yang G, Cao Q, Wang R. The inhibitory role of hydrogen sulfide in airway hyperresponsiveness and inflammation in a mouse model of asthma. Am J Pathol. 2013;182 (4):1188-1195. doi:10.1016/j.ajpath.2012.12.008

170. DiNicolantonio JJ, OKeefe JH, McCarty MF. Boosting endogenous production of vasoprotective hydrogen sulfide via supplementation with taurine and $\mathrm{N}$-acetylcysteine: a novel way to promote cardiovascular health. Open Heart. 2017;4(1):e000600. doi:10.1136/openhrt-2017-000600

171. Sun Q, Wang B, Li Y, et al. Taurine supplementation lowers blood pressure and improves vascular function in prehypertension: randomized, Double-Blind, Placebo-Controlled Study. Hypertension. 2016;67(3):541-549. doi:10.1161/ HYPERTENSIONAHA.115.06624

172. Abebe W, Mozaffari MS. Role of taurine in the vasculature: an overview of experimental and human studies. Am J Cardiovasc Dis. 2011;1(3):293-311.

173. Murakami S. Taurine and atherosclerosis. Amino Acids. 2014;46 (1):73-80. doi:10.1007/s00726-012-1432-6

174. Cortijo J, Blesa S, Martinez-Losa M, et al. Effects of taurine on pulmonary responses to antigen in sensitized Brown-Norway rats. Eur J Pharmacol. 2001;431(1):111-117. doi:10.1016/S00142999(01)01433-9

175. Follmann M, Griebenow N, Hahn MG, et al. The chemistry and biology of soluble guanylate cyclase stimulators and activators. Angew Chem Int Ed Engl. 2013;52(36):9442-9462. doi:10.1002/ anie. 201302588

176. Nossaman B, Pankey E, Kadowitz P. Stimulators and activators of soluble guanylate cyclase: review and potential therapeutic indications. Crit Care Res Pract. 2012;2012:290805. doi:10.1155/2012/290805

177. Ghosh A, Koziol-White CJ, Asosingh K, et al. Soluble guanylate cyclase as an alternative target for bronchodilator therapy in asthma. Proc Natl Acad Sci U S A. 2016;113(17):E2355-E2362. doi:10.1073/pnas.1524398113

178. Koress C, Swan K, Kadowitz P. Soluble guanylate cyclase stimulators and activators: novel therapies for pulmonary vascular disease or a different method of increasing cGMP? Curr Hypertens Rep. 2016;18(5):42. doi:10.1007/s11906-016-0645-6

179. Vesely DL. Biotin enhances guanylate cyclase activity. Science. 1982;216(4552):1329-1330. doi:10.1126/science.6123152

180. Vesely DL, Wormser HC, Abramson HN. Biotin analogs activate guanylate cyclase. Mol Cell Biochem. 1984;60(2):109-114. doi:10.1007/BF00222480

181. Singh IN, Dakshinamurti K. Stimulation of guanylate cyclase and RNA polymerase II activities in HeLa cells and fibroblasts by biotin. Mol Cell Biochem. 1988;79(1):47-55. doi:10.1007/ BF00229397

182. Watanabe-Kamiyama M, Kamiyama S, Horiuchi K, et al. Antihypertensive effect of biotin in stroke-prone spontaneously hypertensive rats. Br J Nutr. 2008;99(4):756-763. doi:10.1017/ S0007114507841122
183. McCarty MF. In type 1 diabetics, high-dose biotin may compensate for low hepatic insulin exposure, promoting a more normal expression of glycolytic and gluconeogenic enyzymes and thereby aiding glycemic control. Med Hypotheses. 2016;95:45-48. doi:10.1016/j.mehy.2016.08.002

184. Tourbah A, Lebrun-Frenay C, Edan G, et al. MD1003 (high-dose biotin) for the treatment of progressive multiple sclerosis: a randomised, double-blind, placebo-controlled study. Mult Scler. 2016;22(13):1719-1731. doi:10.1177/1352458516667568

185. McCarty MF, DiNicolantonio JJ. Neuroprotective potential of high-dose biotin. Med Hypotheses. 2017;109:145-149. doi:10.1016/j.mehy.2017.10.012

186. Mock DM. Biotin: from Nutrition to Therapeutics. J Nutr. 2017;147(8):1487-1492. doi:10.3945/jn.116.238956

187. Zhong Z, Wheeler MD, Li X, et al. L-Glycine: a novel antiinflammatory, immunomodulatory, and cytoprotective agent. Curr Opin Clin Nutr Metab Care. 2003;6(2):229-240. doi:10.1097/ 00075197-200303000-00013

188. McCarty MF, DiNicolantonio JJ. The cardiometabolic benefits of glycine: is glycine an 'antidote' to dietary fructose? Open Heart. 2014;1(1):e000103. doi:10.1136/openhrt-2014-000103

189. Wheeler MD, Rose ML, Yamashima S, et al. Dietary glycine blunts lung inflammatory cell influx following acute endotoxin. Am J Physiol Lung Cell Mol Physiol. 2000;279(2):L390-L398. doi:10.1152/ajplung.2000.279.2.L390

190. Froh M, Thurman RG, Wheeler MD. Molecular evidence for a glycine-gated chloride channel in macrophages and leukocytes. Am J Physiol Gastrointest Liver Physiol. 2002;283(4):G856G863. doi:10.1152/ajpgi.00503.2001

191. Yim PD, Gallos G, Xu D, Zhang Y, Emala CW. Novel expression of a functional glycine receptor chloride channel that attenuates contraction in airway smooth muscle. FASEB J. 2011;25 (5):1706-1717. doi:10.1096/fj.10-170530

192. Vargas MH, Del-Razo-Rodriguez R, Lopez-Garcia A, et al. Effect of oral glycine on the clinical, spirometric and inflammatory status in subjects with cystic fibrosis: a pilot randomized trial. BMC Pulm Med. 2017;17(1):206. doi:10.1186/s12890-017-0528-x

193. Sekhar RV, Patel SG, Guthikonda AP, et al. Deficient synthesis of glutathione underlies oxidative stress in aging and can be corrected by dietary cysteine and glycine supplementation. Am J Clin Nutr. 2011;94(3):847-853. doi:10.3945/ajcn.110.003483

194. Britton J, Pavord I, Richards K, et al. Dietary magnesium, lung function, wheezing, and airway hyperreactivity in a random adult population sample. Lancet. 1994;344(8919):357-362. doi:10.1016/S0140-6736(94)91399-4

195. Hill J, Micklewright A, Lewis S, Britton J. Investigation of the effect of short-term change in dietary magnesium intake in asthma. Eur Respir $J$. 1997;10(10):2225-2229. doi:10.1183/09031936.97.10102225

196. Kazaks AG, Uriu-Adams JY, Albertson TE, Shenoy SF, Stern JS. Effect of oral magnesium supplementation on measures of airway resistance and subjective assessment of asthma control and quality of life in men and women with mild to moderate asthma: a randomized placebo controlled trial. J Asthma. 2010;47 (1):83-92. doi:10.3109/02770900903331127

197. Gontijo-Amaral C, Ribeiro MA, Gontijo LS, Condino-Neto A, Ribeiro JD. Oral magnesium supplementation in asthmatic children: a double-blind randomized placebo-controlled trial. Eur J Clin Nutr. 2007;61(1):54-60. doi:10.1038/sj.ejcn.1602475

198. Bede O, Nagy D, Suranyi A, Horvath I, Szlavik M, Gyurkovits K. Effects of magnesium supplementation on the glutathione redox system in atopic asthmatic children. Inflamm Res. 2008;57 (6):279-286. doi:10.1007/s00011-007-7077-3 
199. Malmendal A, Linse S, Evenas J, Forsen S, Drakenberg T. Battle for the EF-hands: magnesium-calcium interference in calmodulin Biochemistry. 1999;38(36):11844-11850. doi:10.1021/bi9909288

200. Grabarek Z. Insights into modulation of calcium signaling by magnesium in calmodulin, troponin $\mathrm{C}$ and related EF-hand proteins. Biochim Biophys Acta. 2011;1813(5):913-921. doi:10.1016/j.bbamcr.2011.01.017
201. Ohki S, Ikura M, Zhang M. Identification of Mg2+-binding sites and the role of $\mathrm{Mg} 2+$ on target recognition by calmodulin. Biochemistry. 1997;36(14):4309-4316. doi:10.1021/bi962759m

\section{Publish your work in this journal}

The Journal of Asthma and Allergy is an international, peer-reviewed open-access journal publishing original research, reports, editorials and commentaries on the following topics: Asthma; Pulmonary physiology; Asthma related clinical health; Clinical immunology and the immunological basis of disease; Pharmacological interventions and

Submit your manuscript here: https://www.dovepress.com/journal-of-asthma-and-allergy-journal new therapies. The manuscript management system is completely online and includes a very quick and fair peer-review system, which is all easy to use. Visit http://www.dovepress.com/testimonials.php to read real quotes from published authors. 